\title{
Christia Vespertilionis Extract Induced Antiproliferation and Apoptosis in Breast Cancer (MCF7) Cells
}

Noor Zafirah Ismail

Advanced Medical and Dental Institue, Universiti Sains Malaysia

Ismail Abiola Adebayo

Kampala International University - Western Campus

Wan Ahmad Syazani Mohamed

Advanced Medical and Dental Institute, Universiti Sains Malaysia

Nur Nadhirah Mohamad Zain

Advanced Medical and Denta Institute, Universiti Sains Malaysia

Hasni Arsad ( $\nabla$ hasniarsad@usm.my )

Advanced Medical and Dental Institute, Universiti Sains Malaysia

\section{Research Article}

Keywords: Christia vespertilionis, antiproliferative, apoptosis, antioxidant assays, gene expression, gas chromatography-mass spectrometry

Posted Date: July 9th, 2021

DOl: https://doi.org/10.21203/rs.3.rs-665740/v1

License: (c) (1) This work is licensed under a Creative Commons Attribution 4.0 International License. Read Full License 


\section{Abstract}

Background: $C$. vespertiliomis extracts were evaluated for antiproliferative and apoptosis effect on breast cancer (MCF7) cells.

Methods and Results: The leaves extracts were analysed for its antiproliferative effect on breast cancer (MCF7) cells and normal epithelial breast (MCF 10A) cells using Sulforhodamine B (SRB) assay. The selective extract was evaluated for its ability to induce apoptosis using Annexin V-FITC apoptosis staining and the expression of molecular genes using qualitative reverse transcription-polymerase chain reaction (RT-PCR) against MCF7 cells. Gas chromatography-mass spectrometry (GC-MS) was used to identify the compounds from the selective extract. The findings showed that dichloromethane fraction (CV-Dcm) extract had high antiproliferative effect against MCF7 cells $\left(\mathrm{IC}_{50}=24 \mu \mathrm{g} / \mathrm{mL}\right.$, selective index $(\mathrm{SI})=8.17)$. The percentages of apoptosis cells in CV-Dcm-treated MCF7 cells was $58.8 \%$. The CV-Dcm extract induced downregulation of $P C N A$ level. The apoptotic genes were also triggered in both extrinsic and intrinsic signaling pathways, affecting a 1.5-fold increase in $B A X, 1.4$-fold increase in cytochrome $c$, 1.3-fold increase in caspase-8, 1.7-fold increase in caspase-3 and 0.5-fold-decrease in BCL-2. Treated MCF7 cells also activated P53-dependent apoptotic death pathway.

Conclusions: The present work strongly suggests that high efficacy of CV-Dcm extract was attributed to its antiproliferative and apoptosis-inducing activation in MCF7 cells, most likely due to its favourable compounds.

\section{Introduction}

Cancer is caused by rapid proliferation and development of abnormal cells [1]. Global Cancer Incidence, Mortality and Prevalence (GLOBOCAN) (2020) reported that women breast cancer (11.7\%) surpassed lung cancer $(11.4 \%)$ as the most commonly diagnosed cancer [2]. Breast cancer is the most vulnerable among women in Malaysia, with 1 in 19 women are at risk [3]. Krauss and Stickeler [4] estimated that $75.0 \%$ of breast cancer cases have expressed oestrogen receptor as this hormone contributes to uncontrolled growth of breast cells. According to Holliday and Speir [5], breast cancer cell line known as Michigan Cancer Foundation-7 (MCF7) is an ideal model to evaluate hormone response studies.

Christia vespertilionis (L.f.) Bakh. F, which is a member of the Fabaceae family. This plant is used to enhance blood circulation and treat snake bites, bone fractures, tuberculosis, colds and bronchitis. This plant is widely distributed in Southeast Asia and is native to China, Vietnam, Indonesia, Malaysia, Cambodia and Thailand [6]. It is also locally referred as "Butterfly wing" or "Daun Rerama" because of its uniquely shaped trifoliate leaf [7]. Lee at al. [7] showed that $C$. vespertilionis extracts were effective against MCF7 cells. However, there is a knowledge gap to elucidate the antiproliferative and apoptosis molecular mechanism against MCF7 cells. Thus, the objective of this study was to investigate the antiproliferative and apoptosis effect against treated MCF7 cells. Additionally, the gene expression of treated MCF7 cells was also validated through qualitative reverse transcription-polymerase chain reaction 
(RT-PCR). In addition, the compounds from the selective extract were identified using gas chromatography-mass spectrometry (GC-MS).

\section{Methodology}

\section{Plant collection and identification}

C. vespertilionis was obtained from Guar Perahu Herbal Valley, Penang, Malaysia $\left(5.426404{ }^{\circ} \mathrm{N}\right.$, $\left.100.478224^{\circ} \mathrm{E}\right)$. This plant was identified using universal DNA barcode primers $(r b c \mathrm{~L}$, matK, and $t r n \mathrm{H}-$ $p s b A)$ as described by Ismail et al. [8]. The identified DNA sequences have been submitted to National Center for Biotechnology Information (NCBI)'s GenBank. The accession numbers of $C$. vespertilionis's have been retrieved from NCBI's GenBank (MK138830 to MK138849). This plant was authenticated by School of Biological Sciences, Universiti Sains Malaysia and the voucher collection was 11777 (Fig. S1).

\section{Preparation of extracts}

The leaves extract was prepared according to the method by Mohd Fisall et al. [9]The following analytical grade solvents for plant extraction have been obtained from Qrec (Asia) Sdn. Bhd, Malaysia:

Dichloromethane, methanol, $n$-hexane, chloroform, and $n$-butanol. The fresh leaves $(50 \mathrm{~g})$ were soaked and rinsed with distilled water. The leaves were air dried for five days at room temperature $\left(25-30{ }^{\circ} \mathrm{C}\right)$. The crude extract was extracted using $80 \%$ methanol by maceration method using orbital shaker (Buch \& Holm, Denmark) at $170 \mathrm{rpm}$. After $24 \mathrm{~h}$, the crude methanolic extract was filtered using Whatman filter paper No. 1 (Sigma-Aldrich, United States) and the filtrate was extracted again with the same solvent. The maceration process was repeated for three days. The rotary evaporator (Buchi, United States) was used to evaporate the methanol from the crude extract. Then, the crude extract was freeze-dried using freeze dryer (Martin Christ, Germany).

For fraction extract, a portion of the crude extract $(10 \mathrm{~g})$ was dissolved in $100 \mathrm{~mL}$ of distilled water. The dissolved crude extract was transferred to a separatory funnel and subsequently fractionated using $n$ hexane, dichloromethane, chloroform, and $n$-butanol solvents based on the solvent's polarity. The fractionation for each solvent was repeated three times. The solvents from different polarity fraction extracts were evaporated using a rotary evaporator. The crude and fraction extracts were preserved at -20 ${ }^{\circ} \mathrm{C}$ for further used.

\section{Cell culture}

The breast cancer, MCF7 cells and normal epithelial breast (MCF 10A) cells were purchased from American Type Culture Collection (ATCC), United States. The cell culture complete media for MCF7 cells and MCF 10A cells were purchased from Nacalai Tesque, Japan. The MCF7 cells were cultivated in the Roswell Park Memorial Institute culture medium (RPMI-1640) growth medium supplemented with 10\% fetal bovine serum (FBS) and 1\% of penicillin-streptomycin (PenStrep). The MCF 10A cells were cultivated 
in Dulbecco's modified Eagle medium (DMEM) growth medium supplemented with $20 \mathrm{mg} / \mathrm{mL}$ epidermal growth factor (EGF), $0.5 \mathrm{mg} / \mathrm{mL}$ hydrocortisone, $5 \%$ horse serum, $10 \mu \mathrm{g} / \mathrm{mL}$ insulin and $1 \%$ Penstrep.

The cells were incubated in the humidified $5 \%$ carbon dioxide $\left(\mathrm{CO}_{2}\right)$ incubator (Nuaire, United States) at $37^{\circ} \mathrm{C}$. When the cells were ready to be subcultured, the old media was discarded, and the attached cells were rinsed with $4 \mathrm{~mL}$ of phosphate buffered saline (PBS) (Amresco, United States). The $200 \mu \mathrm{L}$ of $0.25 \%$ trypsin-EDTA (GIBCO, United States) was added to the cells. After 5 min, the flask was gently tapped a few times to enhance the trypsinisation process. In order to deactivate the trypsin, $3 \mathrm{~mL}$ of complete media were added to the cells. The cell suspension was transferred to a $15 \mathrm{~mL}$ tube and the tube was centrifuged at $300 \mathrm{xg}$ for $5 \mathrm{~min}$. The supernatant was decanted, and the cells pellet were resuspended with new complete media.

\section{Antiproliferative assay}

The effect of $C$. vespertilionis leaves extracts on antiproliferative activity of MCF7 and MCF 10A were assessed using Sulforhodamine B (SRB) assay, as described by Skehan et al. [10] with minor modifications. In each 96-well plates, the MCF7 and MCF 10A cells $\left(1 \times 10^{4}\right.$ cells $\left./ \mathrm{mL}\right)$ were seeded and incubated in a humidified $5 \% \mathrm{CO}_{2}$ incubator for $24 \mathrm{~h}$. Dimethyl sulfoxide (DMSO) was used to dissolve $C$. vespertilionis extracts. Then, $C$. vespertilionis extracts were serially diluted into six concentration ( 0 to 200 $\mu \mathrm{g} / \mathrm{mL}$ ). The $0.1 \%$ DMSO was used as working solutions of $C$. vespertilionis extracts to ensure that the concentration of DMSO in the cell culture was within the acceptable limit $(0.1-0.5 \%)$ [11]. The $0.1 \%$ DMSO and Tamoxifen (Nacalai Tesque, Japan) were used as a negative and positive control, respectively. The treated cells were incubated in 96-well plates in the humidified $5 \% \mathrm{CO}_{2}$ incubator at $37^{\circ} \mathrm{C}$ for $72 \mathrm{~h}$.

After $72 \mathrm{~h}$, both cells were fixed with $50 \mu \mathrm{L}$ of $50 \%$ cold trichloroacetic acid (fixed solution) for $30 \mathrm{~min}$ at room temperature. Then, the fixed solution was decanted from each well and the plate was washed with distilled water for four times. The cells in each well were stained with $100 \mu \mathrm{L}$ of $0.4 \%$ SRB in $1 \%$ acetic acid for $30 \mathrm{~min}$. The plate was washed again with $1 \%$ acetic acid for four times. The $100 \mu \mathrm{L}$ of $10 \mathrm{mM}$ Tris buffer was transferred to each well and the plate was shaken for $5 \mathrm{~min}$. The cell viability was measured using PowerWave microplate spectrophotometer (Biotek, United States) at $570 \mathrm{~nm}$. The halfmaximal inhibitory concentration $\left(\mathrm{IC}_{50}\right)$ was determined from previous study by Bendale et al. [12]: Cell viability $(\%)=$ Absorbance $($ sample - blank $) /$ Absorbance (control - blank) x 100\%

\section{Selective index (SI)}

The SI values were calculated using Abd Razak et al. [13]'s equation: $\mathrm{SI}=\mathrm{IC}_{50}$ of normal cells (MCF $10 \mathrm{~A}$ )/ $/ \mathrm{C}_{50}$ of cancer cells (MCF7). The highest SI value indicates that the extract was less toxic to normal cells. The selective extract was further analysed for the antiproliferative activity of MCF7 cells at different incubation times $(24,48$, and $72 \mathrm{~h})$.

\section{Cell morphology}


The MCF7 cells $\left(7.5 \times 10^{4}\right.$ cells $\left./ \mathrm{mL}\right)$ were allowed to grow in 6 -well plate. After $24 \mathrm{~h}$, the media was discarded and replaced with complete media mixed with $0.1 \%$ DMSO (negative control) and $\mathrm{IC}_{50}$ of selected extract. The cells were incubated in humidified $5 \% \mathrm{CO}_{2}$ incubator After $72 \mathrm{~h}$, the media was decanted and the cells were stained with $2 \mathrm{~mL}$ acridine orange/propidium iodide (AO/PI) dye $(10 \mu \mathrm{g} / \mathrm{mL})$, which was mixed with the complete media, and incubated for 15 mins. The treated MCF7 cells were observed using fluorescence microscope (Olympus, United States) at 40x magnification.

\section{Apoptosis analysis}

The MCF7 cells $\left(2 \times 10^{5}\right.$ cells $\left./ \mathrm{mL}\right)$ were allowed to grow in the $25 \mathrm{~cm}^{2}$ cell culture flasks for $24 \mathrm{~h}$. The untreated control cells were incubated with $0.1 \%$ DMSO and treated cells were incubated with the $\mathrm{IC}_{50}$ of selected extract. The cells were stained using Annexin V-FITC Kit (Miltenyi Biotec, Germany) and the cells were quantified using Moflo XDP Cell Sorter (Beckman Coulter, United States). The results were analysed in graph plots and percentages of different cell stages.

\section{Gene expression assessment by real-time PCR}

The MCF7 cells were treated as mentioned in apoptosis analysis method. The ribonucleic acid (RNA) of MCF7 cells was extracted using RNeasy Mini Kit (Qiagen, Malaysia). The purity of the extracted RNA was measured using NanoDrop 2000 UV-Vis Spectrophotometer (Thermo Fisher Scientific, United States). The Tetro $^{\text {TM }}$ cDNA Synthesis Kit (Bio line, United Kingdom) has been used to synthesise the complementary DNA (cDNA) according to the manufacturer's instruction. The SensiFAST ${ }^{\mathrm{TM}}$ SYBR ${ }^{\circledR}$ Hi-ROX Kit (Bio line, United Kingdom) was used to determine the expression of proliferating cell nuclear antigen (PCNA), $P 53$, $B A X, B C L-2$, caspase-8 and caspase-3 genes in MCF7 cells. The $\beta$-actin gene was used as an internal control. The gene sequences retrieved from De et al. [14], Devarajan et al. [15], Ferreira and Cronjé [16], Ngoc et al. [17], Priyadarsini et al. [18] were presented in Table S1.

The final volume of each reaction mixture was $10 \mu \mathrm{L}$, comprised of $5 \mu \mathrm{L}$ of $2 x$ SensiFAST SYBRß Hi-ROX Mix, $1 \mu \mathrm{L}$ of synthesized cDNA (10 ng/ $\mu \mathrm{L}), 1 \mu \mathrm{L}$ of forward and reverse primers of each genes $(10 \mu \mathrm{M})$ and $3.2 \mu \mathrm{L}$ of sterile distilled water. The reaction for each gene was biologically repeated three times. The StepOne Plus ${ }^{\text {TM }}$ Real-Time PCR System instrument (Applied BioSystems, United States) was set up to run under following program: an initial denaturation step at $95^{\circ} \mathrm{C}$ for 2 min followed by 40 cycles at $95^{\circ} \mathrm{C}$ for

$5 \mathrm{~s}, 60^{\circ} \mathrm{C}$ for $5 \mathrm{~s}$, and $72^{\circ} \mathrm{C}$ for $20 \mathrm{~s}$. The gene expression was measured using $2^{-\Delta \Delta C T}$ formula to obtain fold change of targeted genes between the untreated and treated MCF7 cells.

\section{Statistical analysis}

The analyses were performed triplicate and Statistical Package for the Social Sciences (SPSS) version 24 was used to carry out the analyses of variance (ANOVA) Tukey's multiple comparison test and student' paired ttest. The $p<0.05$ were considered as significant difference.

\section{GC-MS}


The $1 \mathrm{mg} / \mathrm{mL}$ of selected extract was dissolved with high-performance liquid chromatography (HPLC)grade methanol (Merck, Malaysia). The compound extract was identified using an Agilent gas chromatograph model 6890 equipped with an Agilent 19091S-433 capillary column, HP-5MS (0.25 mm x $30 \mathrm{~m} \times 0.25 \mu \mathrm{m}$ ) (California, United States). The carrier gas, helium was used at $1.0 \mathrm{~mL}$ per minute. The oven was set to the following temperature: $70^{\circ} \mathrm{C}$ was retained for $2 \mathrm{~min}$, then it was elevated to $280^{\circ} \mathrm{C}$ at the rate of $20^{\circ} \mathrm{C}$ per min for $20 \mathrm{~min}$. The GC-MS analysis was run for $32.5 \mathrm{~min}$. The compounds of selected extract were identified by comparing the similarity index of at least $80 \%$ with the compounds from National Institute of Standards and Technology (NIST) library.

\section{Results}

\section{Extraction yield}

Based on Fig. 1, the percentage yield of crude methanolic (CV-Crd) extract was 11.5\%. For fraction extract, the aqueous residue fraction (CV-Aqu) extract was the best at achieving higher extraction yields of $43.8 \%$. The $n$-butanol fraction (CV-But) extract had the second highest percentage yields of $35.1 \%$. Besides that, the dichloromethane fraction (CV-Dcm) extract also had relatively high extraction yield of $32.5 \%$. The extraction yield value for the $n$-hexane fraction (CV-Hex) extract was much lower at $13.4 \%$. However, the lowest extraction yield was chloroform fraction (CV-Chl) extract with a value of $4.7 \%$. The order of the extraction yield of $C$. vespertilionis extracts were as follow; CV-Aqu $>$ CV-But $>$ CV-Dcm $>$ CV-Hex $>$ CV-Crd $>$ $\mathrm{CV}-\mathrm{Chl}$. The results showed that the extraction yield of different solvents differed significantly.

\section{Antiproliferative Activity}

The extracts were analysed on MCF7 and MCF 10A cells for their antiproliferative effect. Figure 2 (a) and Fig. 2 (b) reveal the effects of crude and fraction extracts at various concentration (6.25 to $200 \mu \mathrm{g} / \mathrm{mL})$ on cell viability of MCF7 and MCF $10 \mathrm{~A}$ cells. The findings showed that CV-Dcm had the highest inhibitory effects against MCF7, where the extract inhibited MCF7 cells at the lowest IC $C_{50}$ value of $24 \mu \mathrm{g} / \mathrm{mL}$ followed by CV-Chl extract with $\mathrm{IC}_{50}$ of $74 \mu \mathrm{g} / \mathrm{mL}$, CV-Aqu extract $\left(\mathrm{IC}_{50}=114 \mu \mathrm{g} / \mathrm{mL}\right)$ and CV-But extract $\left(\mathrm{IC}_{50}=190 \mu \mathrm{g} / \mathrm{mL}\right)$.

C. vespertilionis extract were evaluated for the cell viability of MCF 10A cells (Fig. 2 (b)). The CV-Dcm extract inhibited the proliferation of MCF $10 \mathrm{~A}$ cells with $\mathrm{IC}_{50}$ value of $196 \mu \mathrm{g} / \mathrm{mL}$ and had the highest SI value of 8.17 (Table 2). The order of SI values were as follow: CV-Dcm $>\mathrm{CV}$-Hex $>\mathrm{CV}-\mathrm{Chl}>\mathrm{CV}$-Aqu $>\mathrm{CV}$ Crd > CV-But. In Fig. 2 (c), Tamoxifen inhibited the proliferation of MCF7 cells with $I_{50}$ of $6.6 \mu \mathrm{g} / \mathrm{mL}$. According to the results obtained, CV-Dcm selectively inhibited MCF7 cells proliferation while being less toxic to MCF $10 \mathrm{~A}$ cells. Figure 3 illustrated the antiproliferative activity of MCF7 treated with CV-Dcm extract at 24, 48 and $72 \mathrm{~h}$. The antiproliferative effect of CV-Dcm-treated MCF7 cells occurred in a dose and time-dependent manner, where CV-Dcm extract inhibited proliferation of MCF7 cells at IC $\mathrm{C}_{50}$ value of $80 \mu \mathrm{g} / \mathrm{mL}, 68 \mu \mathrm{g} / \mathrm{mL}$ and $24 \mu \mathrm{g} / \mathrm{mL}$ at $24 \mathrm{~h}, 48 \mathrm{~h}$ and $72 \mathrm{~h}$, respectively. 
Table 1

Selective index of antiproliferative activity of MCF7 cells.

\begin{tabular}{|ll|}
\hline Type of extracts & Selective index \\
\hline CV-Crd & 1.4 \\
\hline CV-Hex & 1.9 \\
CV-Dcm & 8.2 \\
CV-Chl & 1.8 \\
CV-But & 1.0 \\
CV-Aqu & 1.7 \\
\hline
\end{tabular}

Table 2

The phytochemical compounds of CV-Dcm extract of $C$. vespertilionis.

\begin{tabular}{|clllll|}
\hline No. & $\begin{array}{l}\text { Retention time } \\
(\mathbf{m i n})\end{array}$ & $\begin{array}{l}\text { Compound } \\
\text { name }\end{array}$ & $\begin{array}{l}\text { Molecular } \\
\text { formula }\end{array}$ & $\begin{array}{l}\text { Area abundance } \\
(\%)\end{array}$ & $\begin{array}{l}\text { Similarity index } \\
(\%)\end{array}$ \\
\hline 1 & 14.66 & $\begin{array}{l}\text { Pentadecyl } \\
\text { acrylate }\end{array}$ & $\mathrm{C}_{18} \mathrm{H}_{34} \mathrm{O}_{2}$ & $28.9 \%$ & 95 \\
\hline 2 & 18.72 & $\begin{array}{l}\text { Methyl } \\
\text { palmitate }\end{array}$ & $\mathrm{C}_{17} \mathrm{H}_{34} \mathrm{O}_{2}$ & $15.9 \%$ & 87 \\
\hline 3 & 19.43 & \begin{tabular}{l} 
Cyclododecane \\
\hline 4
\end{tabular} & $\mathrm{C}_{12} \mathrm{H}_{24}$ & $20.9 \%$ & 90 \\
\hline 5 & 20.08 & $\begin{array}{l}\text { Methyl } \\
\text { linolenate }\end{array}$ & $\mathrm{C}_{19} \mathrm{H}_{32} \mathrm{O}_{2}$ & $23.7 \%$ & 85 \\
\hline
\end{tabular}

\section{Apoptosis Effect}

The morphological changes of MCF7 cells treated with CV-Dcm extract was displayed in Fig. 4. The $\mathrm{AO} / \mathrm{PI}$ staining showed typical apoptosis morphology features such as cell membrane blebbing and nuclear chromatin fragmentation. Annexin V-FITC and propidium iodide (PI) were used to analyse the cells condition in the treated MCF7 cells using flow cytometry. Figure 5 displays the apoptotic level of treated MCF7 cells after $72 \mathrm{~h}$ treatment. The rate of total apoptosis (early and late apoptosis) in treated MCF7 cells was $58.8 \pm 2.3 \%$ at $72 \mathrm{~h}$.

The RT-PCR of the selected gene expression further supports the antiproliferative and apoptosis effect of treated MCF7 cells. The fold change of the targeted genes was determined using the $2^{-\triangle \triangle C T}$ formula and normalised to housekeeping gene ( $\beta$-actin). As shown in Fig. 6, the CV-Dcm-treated MCF7 cells had caused significant upregulation of $P 53(1.4 \pm 0.13), B A X(1.5 \pm 0.12)$, cytochrome c $(1.4 \pm 0.12)$, caspase-8 
(1.3 \pm 0.12$)$ and caspase-3 $(1.7 \pm 0.12)$ and downregulation of $B C L-2(0.5 \pm 0.13)$ compared to untreated control cells. Thus, this study exhibited that CV-Dcm extract significantly activated the intrinsic and extrinsic of apoptosis pathway. Interestingly, PCNA level in treated MCF7 cells decreased by $0.63 \pm 0.13$ compared with untreated control MCF7 cells.

\section{Phytochemistry Screening}

Five compounds were obtained from GC-MS analysis where the similarity indices of the compounds were more than $80 \%$ with known NIST library (Fig. 7). The GC-MS showed the presence of phytochemical compounds known as pentadecyl acrylate (28.9\%), methyl palmitate (15.9\%), cyclododecane $(20.9 \%)$, methyl linolenate (23.7\%) and phytol (10.7\%) (Table 3).

\section{Discussion}

Non-polar to polar solvents were used as fraction solvents to remove and purify various components found in the crude methanolic extract. In this study, fraction solvents were consecutively fractionated from the crude methanolic extract due to the fact that fraction extracts may have high inhibition effects against cancer cells [19]. The extraction yields of $C$. vespertilionis extracts were in line with the study by Ismail et al. [20], which showed the similar results with the percentage yield of Clinacanthus nutans extracts. CV-Aqu extract was best at achieving higher extraction than other solvents. The highest yields of CV-Aqu could be attributed to high impurities like organic acids, sugars and soluble proteins with polar compounds. This findings were in line with Anwar et al. [21], who reported that the highest extraction yield came from the aqueous extract from Brassica oleracea.

The CV-Dcm extract exhibited strongest IC ${ }_{50}$ value when treated with MCF7 cells. The finding was concurrent with a report from Sidek et al. [22] who revealed that the dichloromethane fraction extract of $C$. vespertilionis exhibited the strongest extract when treated with cervical cancer (HeLa) cells at $72 \mathrm{~h}$. The $\mathrm{IC}_{50}$ of $\mathrm{CV}$-Dcm extract also met the requirement of the National Cancer Institute, which requires the extracts to have an $\mathrm{IC}_{50}$ less than $30 \mu \mathrm{g} / \mathrm{mL}$ for preliminary assay [23]. Furthermore, CV-Dcm extract had the highest SI value in which the extract with SI value more than 2 was considered to have high selectivity [24].

It was found that the treated MCF7 cells induced apoptosis when phosphatidylserine (PS) of the cellular membrane is exposed to the Annexin V [25]. Hence, it is important to validate the expression of molecular mechanism of the CV-Dcm-treated MCF7 cells. The CV-Dcm extract upregulated the gene expressions of $P 53, B A X$, cytochrome $C$, caspase-8 and caspase- 3 and downregulate the gene expressions of $B C L-2$ and $P C N A$ in the MCF7 cells (Fig. 7). The result showed that the increased level of $P 53$ suggested that the extract could lead to apoptosis through extrinsic pathway [26]. Besides that, $P 53$ also interacts with $B A X$ or $B A K$ to trigger the intrinsic pathway [27]. The present study showed decreased level of $B C L-2$ and increased level of $B A X$ in treated MCF7 cells. This study validates that $B C L-2$ in treated MCF7 cells could 
not protect the integrity of mitochondrial membrane [28] and enhanced the level of $B A X$ which is necessary for the pores creation in the mitochondrial membrane, resulting in the cytochrome $c$ released, followed by the caspase-3 activation. Importantly, caspase- 8 can also regulates the expression of the extrinsic apoptotic pathway [29]. Notably, the significant PCNA downregulation explained the proliferative inhibition of MCF7 cells induced by CV-Dcm extract which has not been noted in any $C$. vespertilionis studies. PCNA level in treated MCF7 cells was approximately lower compared to untreated control MCF7 cells. The findings suggested that the decreased in PCNA expression could be responsible for the suppression in MCF7 cells growth. This study showed the remarkable effectiveness of the CV-Dcm extract on MCF7 cells due to activation of the apoptosis and antiproliferative effects.

The GC-MS analysis revealed five phytochemical compounds found in CV-Dcm extract. Previous studies revealed that pentadecyl acrylate has antioxidant activity [30]. Additionally, the had cytotoxicity activities on T-cell leukemia cell line [31]. Methyl palmitate may be the basis of the antiproliferative and apoptosis effect on treated MCF7 cells. Cyclododecane is said to be antimicrobial and antitumour [32] and methyl linolenate is reported as anti-inflammatory, cancer preventive, hypocholesterolaemia and hepatoprotective [33]. Phytol has been shown to contain a variety of medicinal properties such as antitumoral and anticarcinogenic effects [34]. However, the chemical compounds may differ because most of the plants are largely influenced by climate variables such as humidity, water content, temperature, soil pH changes and nutrient content [35] that will also interfere with plant genetics, leading to genetic variations that can influence the content of plant materials [36].

\section{Conclusion}

In conclusion, the results showed that CV-Dcm suppressed MCF7 cells proliferation due to the downregulation of PCNA level. This extract also induced apoptosis against MCF7 cells through both intrinsic and extrinsic pathways and caused $P 53$-dependent apoptotic deaths. Hence, the $C$. vespertilionis extract seems to be a potential source for anti-cancer agents. research.

\section{Declarations}

\section{Acknowledgements}

The first author gratefully acknowledges Universiti Sains Malaysia for fellowship under the Universiti Sains Malaysia Fellowship Scheme.

\section{Author contributions}

NZI and HA designed the experiment. NZI performed the experiments. NZI, IAA, WASM, NNMZ and HA analysed the data. NZI, WASM and IAA wrote the manuscript. NZI, IAA, WASM, NNMZ and HA has given the final shape of manuscript and all authors approved the manuscript.

\section{Conflict of Interest}


The authors have declared that there is no conflict of interest.

\section{References}

1. Reed JC (1999) Dysregulation of apoptosis in cancer. J Clin Oncol 17:2941-2953. https://doi.org/10.1200/JC0.1999.17.9.2941

2. Sung H, Ferlay J, Siegel RL, et al (2021) Global Cancer Statistics 2020: GLOBOCAN estimates of incidence and mortality worldwide for 36 cancers in 185 countries. CA Cancer J Clin 1-41. https://doi.org/10.3322/caac.21660

3. Lee MS, Ma'ruf CA, Izhar DPN, et al (2019) Awareness on breast cancer screening in Malaysia: a cross sectional study. BioMedicine 9:19-25. https://doi.org/10.1051/bmdcn/2019090318

4. Krauss K, Stickeler E (2020) Endocrine Therapy in Early Breast Cancer. Breast Care 15:337-346. https://doi.org/10.1159/000509362

5. Holliday DL, Speirs V (2011) Choosing the right cell line for breast cancer research. Breast Cancer Res 13:1-7. https://doi.org/10.1186/bcr2889

6. Bunawan H, Bunawan SN, Baharum SN (2015) The red butterfly wing (Christia vespertilionis): a promising cancer cure in Malaysia. Int J Pharm Pharm Sci 7:1

7. Lee JJ, Saiful Yazan L, Kassim NK, et al (2020) Cytotoxic activity of Christia vespertilionis root and leaf extracts and fractions against breast cancer cell lines. Molecules 25:2610

8. Ismail NZ, Arsad H, Samian MR, et al (2018) Assessment of three plastid DNA barcode markers for identification of Clinacanthus nutans (Acanthaceae). 3 Biotech 8:1-8. https://doi.org/10.1007/s13205-018-1092-7

9. Mohd Fisall UF, Ismail NZ, Adebayo IA, Arsad H (2021) Dichloromethane fraction of Moringa oleifera leaf methanolic extract selectively inhibits breast cancer cells (MCF7) by induction of apoptosis via upregulation of Bax, p53 and caspase 8 expressions. Mol Biol Rep 1-11

10. Skehan P, Storeng R, Scudiero D, et al (1990) New colorimetric cytotoxicity assay for anticancer-drug screening. J Natl Cancer Inst 82:1107-1112. https://doi.org/10.1093/jnci/82.13.1107

11. Scambia G, Ranelletti FO, Panici PB, et al (1994) Quercetin potentiates the effect of adriamycin in a multidrug-resistant MCF-7 human breast-cancer cell line: P-glycoprotein as a possible target. Cancer Chemother Pharmacol 34:459-464. https://doi.org/10.1007/BF00685655

12. Bendale Y, Bendale V, Paul S (2017) Evaluation of cytotoxic activity of platinum nanoparticles against normal and cancer cells and its anticancer potential through induction of apoptosis. Integr Med Res 6:141-148. https://doi.org/10.1016/j.imr.2017.01.006

13. Abd Razak N, Abu N, Ho WY, et al (2019) Cytotoxicity of eupatorin in MCF-7 and MDA-MB-231 human breast cancer cells via cell cycle arrest, anti-angiogenesis and induction of apoptosis. Sci Rep 9:112. https://doi.org/10.1038/s41598-018-37796-w

14. De AK, Muthiyan R, Mondal S, et al (2019) A natural quinazoline derivative from marine sponge hyrtios erectus induces apoptosis of breast cancer cells via ROS production and intrinsic or extrinsic 
apoptosis pathways. Mar Drugs 17:1-20. https://doi.org/10.3390/md17120658

15. Devarajan E, Sahin AA, Chen JS, et al (2002) Down-regulation of caspase 3 in breast cancer: a possible mechanism for chemoresistance. Oncogene 21:8843-8851.

https://doi.org/10.1038/sj.onc.1206044

16. Ferreira E, Cronjé MJ (2012) Selection of suitable reference genes for quantitative real-time PCR in apoptosis-induced MCF-7 breast cancer cells. Mol Biotechnol 50:121-128.

https://doi.org/10.1007/s12033-011-9425-3

17. Ngoc TTB, Nga NTH, Trinh NTM, et al (2020) Elephantopus mollis Kunth extracts induce antiproliferation and apoptosis in human lung cancer and myeloid leukemia cells. J Ethnopharmacol 263:113222. https://doi.org/10.1016/j.jep.2020.113222

18. Priyadarsini RV, Murugan RS, Maitreyi S, et al (2010) The flavonoid quercetin induces cell cycle arrest and mitochondria-mediated apoptosis in human cervical cancer ( $\mathrm{HeLa}$ ) cells through p53 induction and NF-KB inhibition. Eur J Pharmacol 649:84-91. https://doi.org/10.1016/j.ejphar.2010.09.020

19. Adebayo IA, Arsad H, Samian MR (2017) Antiproliferative effect on breast cancer (MCF7) of Moringa oleifera seed extracts. Afr J Tradit Complement Altern Med 14:282-287. https://doi.org/10.21010/ajtcam.v14i2.30

20. Ismail NZ, Md Toha Z, Muhamad M, et al (2020) Antioxidant effects, antiproliferative effects, and molecular docking of Clinacanthus nutans leaf extracts. Molecules 25:1-18. https://doi.org/10.3390/molecules25092067

21. Anwar F, Kalsoom U, Sultana B, et al (2013) Effect of drying method and extraction solvent on the total phenolics and antioxidant activity of cauliflower (Brassica oleracea L.) extracts. Int Food Res J 20:1-7

22. Sidek MM, Ismail NZ, Mohamad Zain NN, Arsad H (2019) Cytotoxicity activity of Christia vespertilionis leaves extracts against HeLa cells and the detection of compounds by GC-MS. J Biol Sci Opin 7:71-78

23. Fadeyi SA, Fadeyi 00, Adejumo AA, et al (2013) In vitro anticancer screening of 24 locally used Nigerian medicinal plants. BMC Complement Altern Med 13:1-10. https://doi.org/10.1186/14726882-13-79

24. Mohamed WAS, Ismail NZ, Omar EA, et al (2020) GC-MS evaluation, antioxidant content, and cytotoxic activity of propolis extract from Peninsular Malaysian stingless bees, Tetrigona apicalis. Evidence-Based Complement Altern Med 2020:1-9. https://doi.org/10.1155/2020/8895262

25. Vermes I, Haanen C, Steffens-Nakken H, Reutellingsperger C (1995) A novel assay for apoptosis flow cytometric detection of phosphatidylserine expression on early apoptotic cells using fluorescein labelled annexin V. J Immunol Methods 184:39-51. https://doi.org/10.1016/0022-1759(95)00072-I

26. Aubrey BJ, Kelly GL, Janic A, et al (2018) How does p53 induce apoptosis and how does this relate to p53-mediated tumour suppression? Cell Death Differ 25:104-113.

https://doi.org/10.1038/cdd.2017.169

Page $11 / 15$ 
27. Vaseva A V, Moll UM (2009) The mitochondrial p53 pathway. Biochim Biophys Acta (BBA)Bioenergetics 1787:414-420. https://doi.org/10.1016/j.bbabio.2008.10.005

28. Chipuk JE, Green DR (2008) How do BCL-2 proteins induce mitochondrial outer membrane permeabilization? Trends Cell Biol 18:157-164. https://doi.org/10.1016/j.tcb.2008.01.007

29. Mooney LM, Al-Sakkaf KA, Brown BL, Dobson PRM (2002) Apoptotic mechanisms in T47D and MCF7 human breast cancer cells. Br J Cancer 87:909-917. https://doi.org/10.1038/sj.bjc.6600541

30. Huang B, Ban X, He J, et al (2010) Comparative analysis of essential oil components and antioxidant activity of extracts of Nelumbo nucifera from various areas of China. J Agric Food Chem 58:441448. https://doi.org/10.1021/jf902643e

31. Takeara R, Jimenez PC, Wilke DV, et al (2008) Antileukemic effects of Didemnum psammatodes (Tunicata: Ascidiacea) constituents. Comp Biochem Physiol Part A Mol Integr Physiol 151:363-369. https://doi.org/10.1016/j.cbpa.2007.02.011

32. Paramanantham M, Murugesan A (2014) GC-MS analysis of Holarrhena antidysentrica Wall flower. Int J Sci Eng Technol Res 3:631-639

33. Devi J, Muthu AK (2014) Gas chromatography-mass spectrometry analysis of bioactive constituents in the ethanolic extract of Saccharum spontaneum Linn. Int J Pharm Pharm Sci 6:755-759

34. Suri S, Kathuria D, Mishra A, Sharma R (2020) Phytochemical composition and pharmacological impact of natural non-calorie sweetener-monk fruit (Siraitia grosvenorii): a review. Nutr Food Sci 114. https://doi.org/10.1108/nfs-09-2020-0350

35. Ismail NZ, Arsad H, Samian MR, Hamdan MR (2017) Determination of phenolic and flavonoid contents, antioxidant activities and GC-MS analysis of Clinacanthus nutans (Acanthaceae) in different locations. Agrivita, J Agric Sci 39:335-344. https://doi.org/10.17503/agrivita.v39i3.1076

36. Ismail NZ, Arsad H, Samian MR, et al (2016) Evaluation of genetic diversity of Clinacanthus nutans (Acanthaceaea) using RAPD, ISSR and RAMP markers. Physiol Mol Biol Plants 22:523-534. https://doi.org/10.1007/s12298-016-0391-x

\section{Figures}




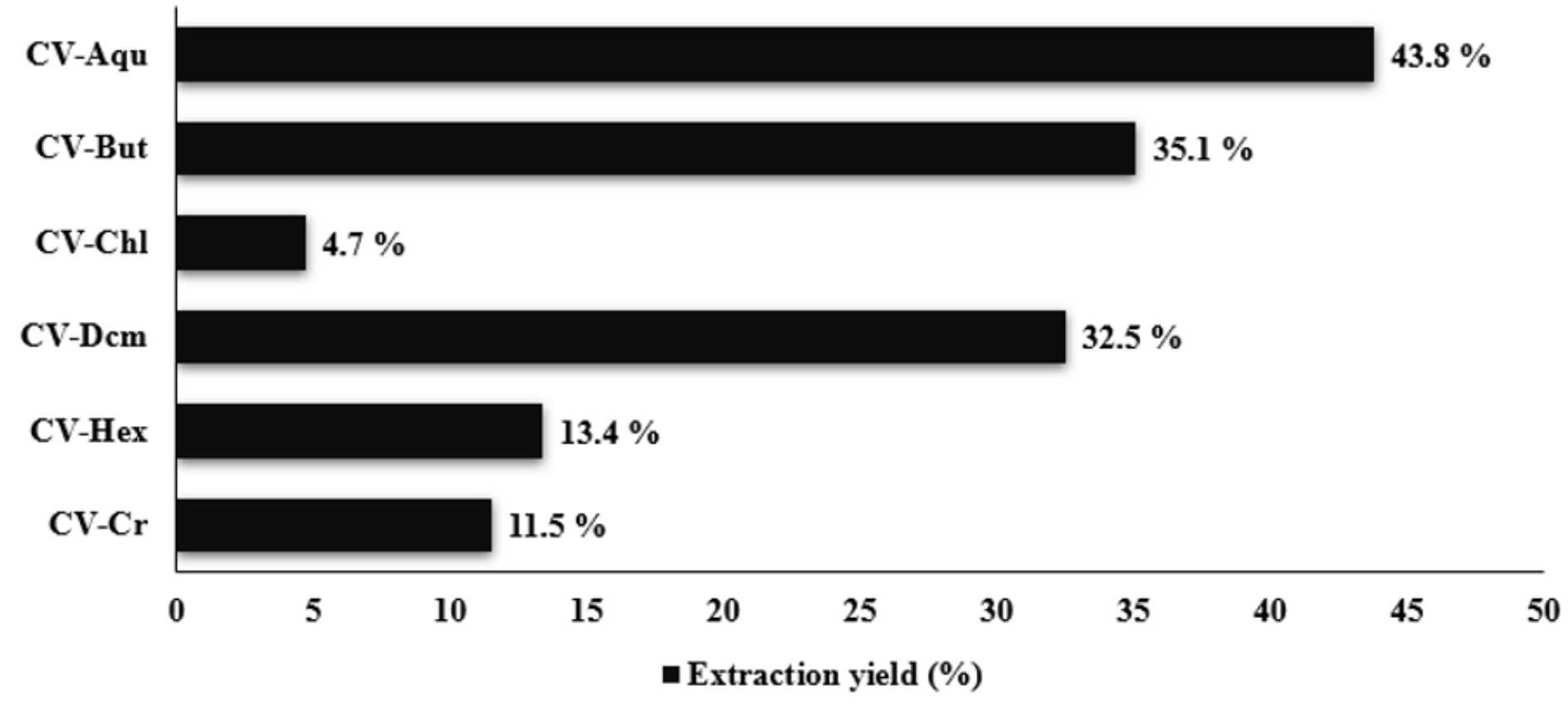

\section{Figure 1}

The extraction yield (\%) of dried leaves of C. vespertilionis.

a)

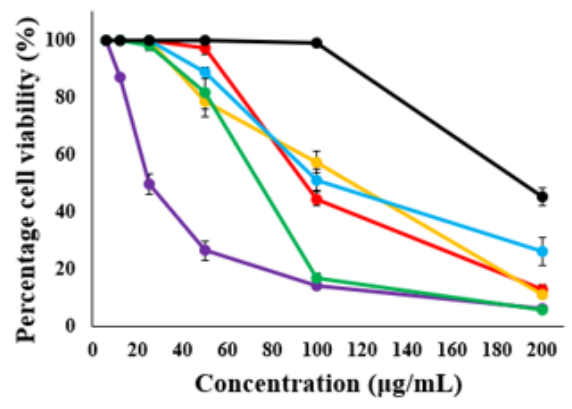

c)

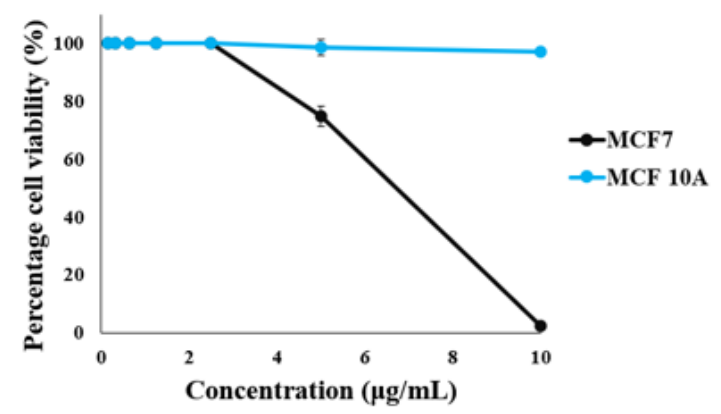

b)

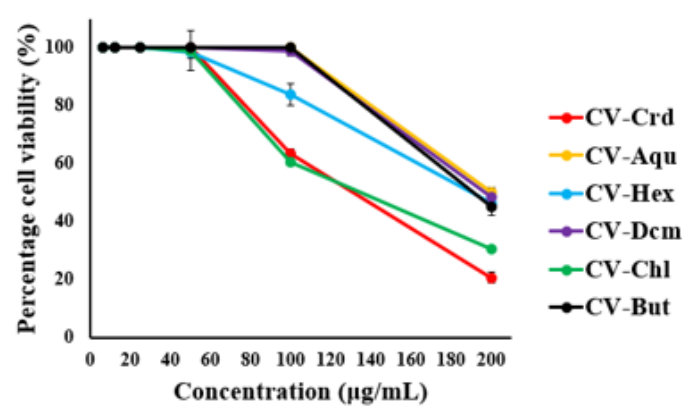

d)

\begin{tabular}{lcc}
\hline Type of extracts & \multicolumn{2}{c}{ IC $_{\mathbf{5 0}}(\boldsymbol{\mu} \mathbf{g} / \mathbf{m L})$} \\
\cline { 2 - 3 } & $\mathbf{M C F} 7$ & $\mathbf{M C F} \mathbf{~ 1 0 A}$ \\
\hline CV-Crd & 94 & 134 \\
CV-Hex & 100 & 190 \\
CV-Dcm & 24 & 196 \\
CV-Chl & 74 & 130 \\
CV-But & 190 & 190 \\
CV-Aqu & 114 & 198 \\
Tamoxifen & 6.6 & $>10$ \\
\hline
\end{tabular}

\section{Figure 2}

Antiproliferative effect of MCF7 and MCF 10A cells. a) Antiproliferative effect of MCF7 cells; b) Antiproliferative effect of MCF 10A; c) Antiproliferative effect of MCF7 and MCF 10A treated with 
Tamoxifen; d) The IC50 value of MCF7 and MCF 10A cells.

a)

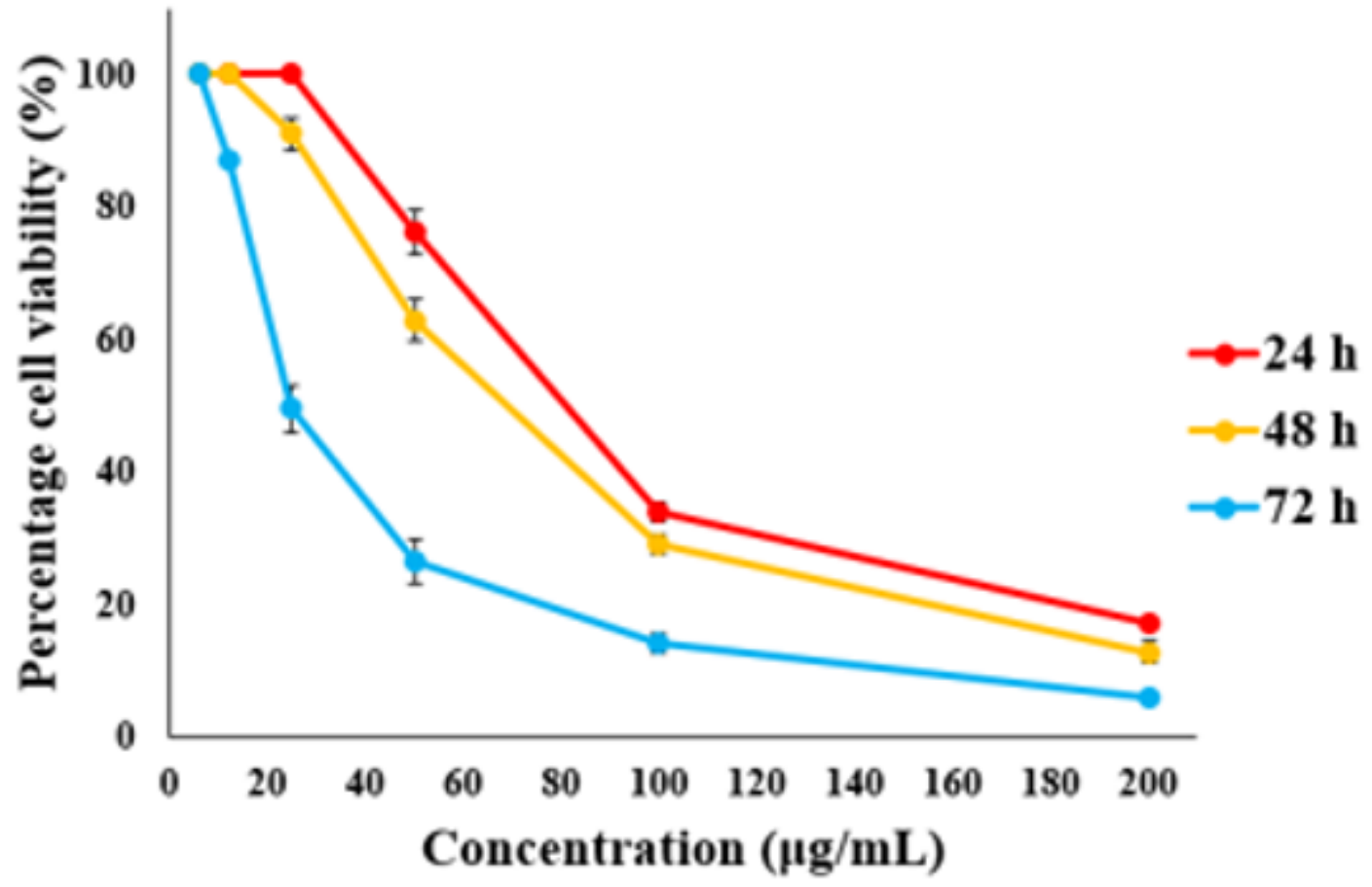

b)

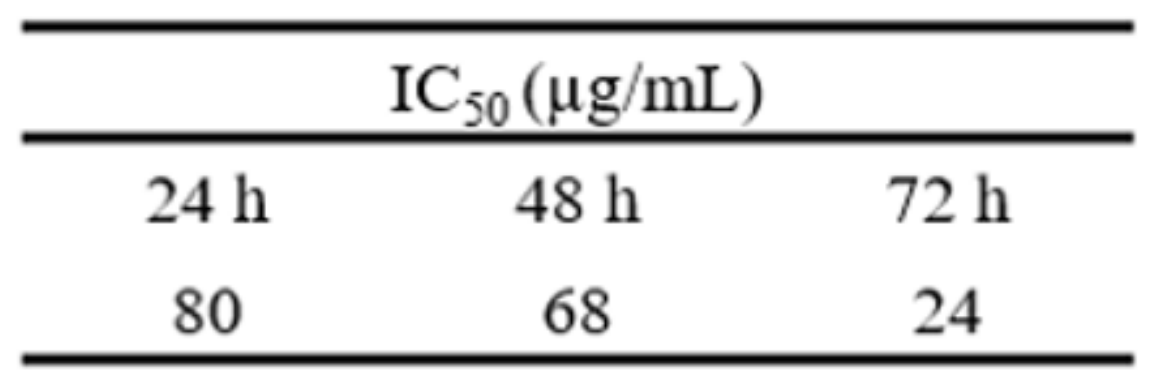

Figure 3

Antiproliferative effect of CV-Dcm against MCF7 at time-dependent manner. a) Antiproliferative effect of MCF7 cells at 24, 48 and $72 \mathrm{~h}$; b) The IC50 of MCF7 cells at 24, 48 and $72 \mathrm{~h}$. 
a)

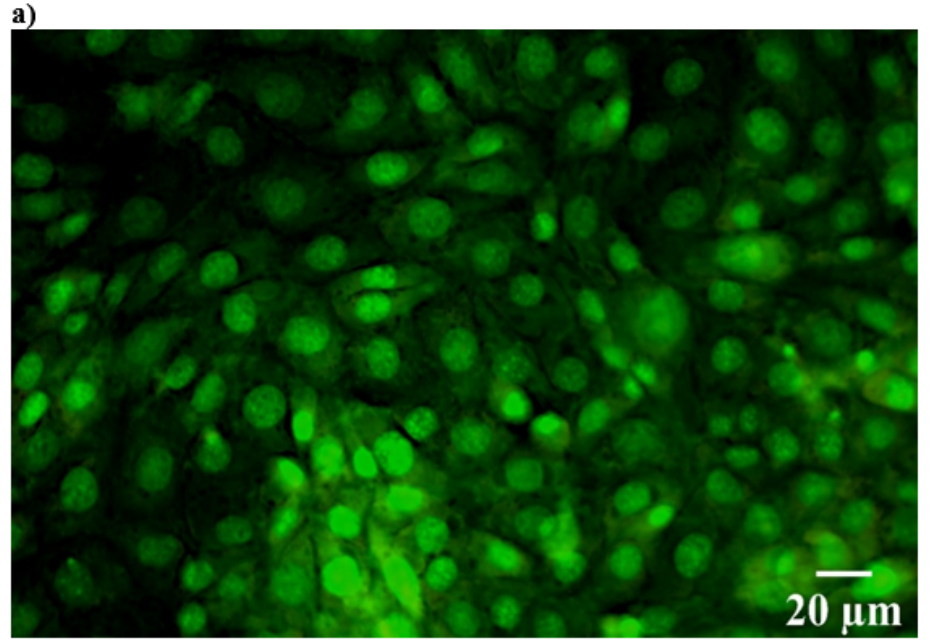

b)

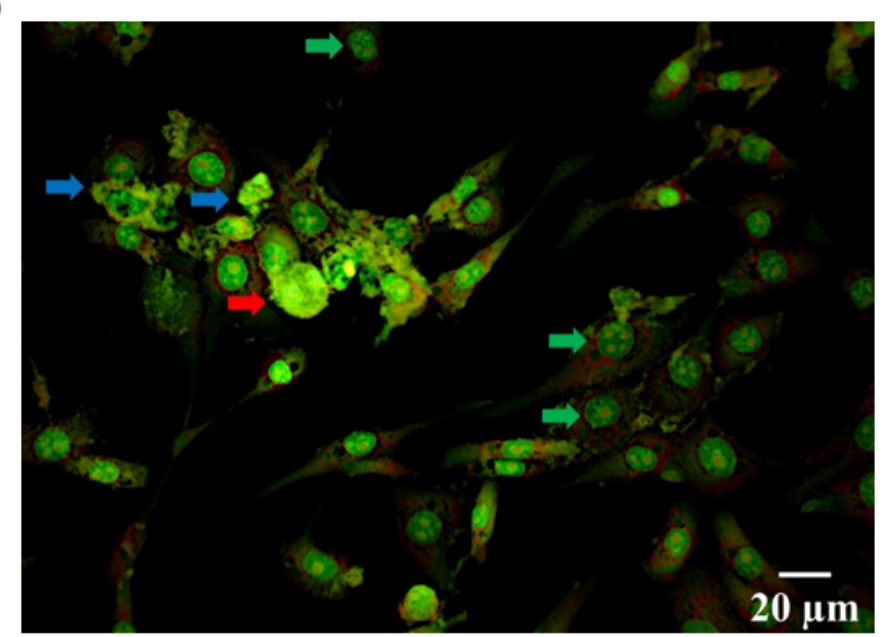

Figure 4

Morphology of treated MCF7 cells using AO/PI staining. a) Untreated control cells; b) Treated cells. Untreated control cells exhibit normal morphologies. Treated cells showed the typical characteristic of apoptosis such as nuclear chromatin fragmentation (green arrow), cell membrane blebbing (red arrow) and apoptotic bodies (blue arrows).

\section{Supplementary Files}

This is a list of supplementary files associated with this preprint. Click to download.

- Supplementarymaterial.docx 